Mirko Pejanović

\title{
INTERPRETACIJA ODGOVORA ISPITANIKA - PRAVOSLAVACA NA POSTAVLJENA PITANJA NA PROJEKTU "KOLIKO SE POZNAJEMO”
}

U odgovoru na postavljena pitanja sa stanovišta radnog statusa učestvovali su sljedeći ispitanici: zaposleni kod nekog (privatni, državni i javni sektor) ukupno 3,2 \%; samostalno zaposleni ispitanici učestvuju sa 1,6 \%; skupina nezaposlenih ispitanika učestvuje sa $12,7 \%$; poljoprivrednici, ribari, itd. učestvuju sa $8 \%$. Učenici i studenti su najbrojnija skupina ispitanika ukupno 77,8 \%. Umirovljenici/penzioneri kao ispitanici učestvuju sa $8 \%$, a onih koji se nisu izjasnili je bilo 3,2\%.

$\mathrm{Na}$ pitanje da li ste pohađali vjersku pouku/vjeronauku odgovorilo je potvrdno $94,9 \%$, samo $4,4 \%$ je odgovorilo da nisu pohađali vjeronauku, dok odgovor nisu dali njih $7 \%$. Na pitanje gdje su pohađali vjeronauku ispitanici su sa $100 \%$ vrijednosti odgovorili da je to bilo u školi.

Koliko često posjećujete vjerske objekte? Na ovo pitanje ispitanici su dali više odgovora: najmanje jednom sedmično 9,2 \%, više puta mjesečno 23,4 \%. Jedanput mjesečno vjerske objekte posjećuje $22 \%$ ispitanika. Samo za velike vjerske praznike/blagdane crkvu posjećuje 30,5\% ispitanika. Jednom godišnje i rjeđe crkvu posjećuje 2,1 \% ispitanika. Vidljivo je da najviši procent ispitanika, zapravo 30,5\% ispitanika, crkvu posjećuje u vrijeme velikih vjerskih praznika/blagdana.

Kako rijetko ili nikad ne odlaze u vjerske objekte, ispitanici su naveli i razloge zašto je to tako. Zbog nepovjerenja u religijske institucije u crkvu ne ide $11,5 \%$ ispitanika. Razočaranost u moralnost je razlog za $25 \%$ ispitanika što ne posjećuju religijske institucije. Jedan dio ispitanika, njih 1,9\% ne odlazi u vjerske institucije zbog toga što se često u njima govori o politici. Udaljenost vjerskog objekta od mjesta stanovanja razlog je za 5,8 \% ispitanika što rijetko ili nikako ne odlaze u vjerske objekte. Za rijetke odlaske u vjerske objekte njih 5,8\% je navelo neke druge razloge. Odgovore nije dalo $50 \%$ ispitanika.

Na pitanje posjedujete li Kur'an u kući potvrdno je odgovorilo 27,3\% ispitanika. Istovremeno je 72,7 \% ispitanika odgovorilo da Kur'an ne posje- 
duje. U pogledu posjedovanja Talmuda u kući $47 \%$ ispitanika je potvrdilo da Talmud posjeduju u kući dok je 52,6 \% kazalo da ga ne posjeduju.

Da li posjedujete u kući Bibliju ili NoviZavjet potvrdnoje odgovorilo 87,2\% ispitanika. Samo 11,5 \% ispitanika ne posjeduje Bibliju ili Novi Zavjet.

Čitanje Kur>ana je potvrdilo $100 \%$ ispitanika od onih koji su kazali da ga posjeduju. Na pitanje koliko često čitate Kur'an ili dijelove, odgovori su bili sljedeći: nekoliko puta nedjeljno 3,8 \%, ponekad 7,7\%, veoma rijetko 11,5\%. Bez odgovora imamo 73,1\% ispitanika.

Koliko često čitate Bibliju ili dijelove Novog Zavjeta, odgovori se javljaju na sljedeći način: svaki dan čita 3,8 \% ispitanika, nekoliko puta nedjeljno 4,8 \% ispitanika. Ponekad Bibliju čita 21,9 \% ispitanika, veoma rijetko 41,9\%. Odgovor da ne zna dalo je $8,6 \%$ ispitanika, a potpuno bez odgovora je bilo $19 \%$ ispitanika.

Biblija sadrži dva dijela i možete li navesti njihove nazive? Na ovo pitanje potvrdan odgovor je dalo $88 \%$ ispitanika. Da ne znaju odgovorilo je 4,5 \% ispitanika. Bez odgovora je bilo 7,5\% ispitanika.

Na pitanje šta je prvi dio Biblije, $81 \%$ ispitanika je odgovorilo da je to Stari Zavjet, a samo 2,1 \% da je to Novi Zavjet. Također, ispitanici za drugi dio Biblije odgovaraju sa $80,3 \%$ da je to Novi Zavjet. Da je Sveto Pismo drugi dio Biblije odgovorilo je $7 \%$ ispitanika.

Na pitanje kako se nazivaju poglavlja koja sačinjavaju Kur'an odgovor nije znalo 79,3 \% ispitanika. Samo je 20,7 \% ispitanika odgovorilo da zna kako se nazivaju poglavlja koja čine Kur'an. U pokušaju da se navedu poglavlja Kur'ana, ispitanici odgovaraju: ožuzevi $7 \%$, sura 2,1 \%, sure 1,4\% i sure $7,7 \%$.

Šta ispitanici misle koji od navedenih gradova ima izuzetnu važnost i za hrišćane i za muslimane, i za jevreje, uslijedili su sljedeći odgovori: grad Rim ima važnost za 7,7 \% ispitanika; Istanbul ima važnost za 3,6 \% ispitanika. Nijedan grad ne prepoznaje 3,6 \% a bez odgovora je bilo 9,4 \% ispitanika. Ispitanici - pravoslavci su odgovorili sa $79,7 \%$ da ima najveću važnost grad Jeruzalem.

Na pitanje koje religije spadaju u abrahamske, $61,4 \%$ ispitanika je odgovorilo da zna, a da ne zna odgovorilo je $38,6 \%$ ispitanika. U navođenju 50 naziva za odgovor, $12,7 \%$ ispitanika je navelo da su abrahamske religije: hrišćanstvo, islam i judaizam.

U upitniku je bilo i pitanje da li ispitanici znaju iz koje su zemlje došli Sefardi u Bosnu i Hercegovinu nakon progona. Najviše ispitanika, zapravo 30,2 \% njih je navelo da su Sefardi stigli iz Njemačke. Da su doselili iz 
Španije odgovorilo je 21,7 \% ispitanika. Da uopšte ne znaju odgovorilo je $43,4 \%$ ispitanika. Istovremeno je 4,7 \% ispitanika odgovorilo da su Sefardi doselili iz Italije.

Na pitanje da li znate kome je Bog objavio 10 zapovijedi uslijedili su sljedeći odgovori: Ivanu/Jovanu Krstitelju - 1,5 \% ispitanika; Mojsiju 87,1 \% ispitanika. Da je Abrahamu/Avramu/Ibrahimu Bog objavio 10 zapovijedi odgovorilo je 4,5\% ispitanika.

Da li znate navesti 10 Božijih zapovijedi, 87,2 \% ispitanika potvrdilo je da zna. Bez odgovora je bilo 12,8 \% ispitanika. U pokušaju da ispitanici navedu neke od 10 Božijih zapovijedi, uslijedili su sljedeći odgovori: 9 uredno navedeno od $7 \%$ ispitanika; 2 navedeno od 2,1\%; 1 zapovijed uredno navedena od $7 \%$ ispitanika. Nekoliko uredno navedenih zapovijedi iskazalo je $7 \%$ ispitanika.

Pripadnici židovske vjere u svojim obredima se služe Hagadom bilo je pitanje na osnovu kojeg se ispitalo koliko ispitanici poznaju jevrejske obrede. U odgovorima, ispitanici su sa $10 \%$ potvrdili da se za vrijeme Hanuke služi Hagadom. Nadalje, 9,2 \% ispitanika potvrđuje da se Hagadom koriste jevreji za vrijeme Pesaha. Bez odgovora je bilo $80,8 \%$ ispitanika.

Pesah je jevrejski praznik u čast: pobjede za samostalnost Judeje - ovaj odgovor je dalo 3,1 \% ispitanika. U čast berbe voća $-7,8 \%$. Da je blagdan u čast izlaska iz egipatskog ropstva potvrdilo je 28,7 \% ispitanika. Bez odgovora je bilo 60,5 \% što pokazuje da pravoslavci nemaju dovoljno znanja o Pesahu kao židovskom blagdanu.

Na pitanje ko su pisci 4 Evanđelja ispitanici su odgovorili sljedeće: da su bili Matej, Petar, Luka, Ivan/Jovan odgovorilo je 6,7 \% ispitanika. Da su bili Pavle, Marko, Matej, Luka odgovorilo je 19,4 \%. Da su bili Ivan/Jovan, Pavle, Petar, Luka potvrdilo je 3,7 \% ispitanika. Da su bili Matej, Marko, Luka i Ivan/Jovan potvrdilo je 59,7 \% ispitanika. Bez odgovora je bilo 10,4 \% ispitanika.

Da li vjerujete u postojanje Boga, 95,1 \% ispitanika je odgovorilo potvrdno. $2,1 \%$ ispitanika nije bilo sigurno. Da ne vjeruju bilo je $7 \%$ ispitanika, a bez odgovora je bilo $2,1 \%$ ispitanika.

U postojanje duše vjeruje $85,4 \%$ ispitanika. Među ispitanicima nije sigurno njih $8,8 \%$, da ne vjeruju se izjasnilo $1,5 \%$, a bez odgovora je bilo $4,4 \%$ ispitanika.

Vjerovanje u postojanje zagrobnog života je potvrdilo 55,2 \% ispitanika. Potom 30,6 \% ispitanika nije sigurno. Istovremeno ne vjeruje $8,2 \%$, a bez odgovora je bilo $6 \%$ ispitanika. 
Da li vjerujete u postojanje raja/dženeta potvrdno je odgovorilo 59,2 \%. Nije sigurno njih $23,8 \%$, a da ne vjeruju iskazalo je $7,7 \%$ ispitanika. Bez odgovora je bilo 9,2\%.

Kada je u pitanju postojanje vraga/sotone/šejtana odgovori ispitanika su bili iskazani na sljedeći način: 42,7 \% ispitanika vjeruje; nije sigurno 25,2 \% ispitanika; ne vjeruje $22 \%$, a bez odgovora je bilo $9,9 \%$.

Vjerovanje u postojanje pakla/džehenema je pozitivno iskazalo $48 \%$ ispitanika. Nije sigurno vrijedi za $29 \%$ ispitanika. Nadalje, da ne vjeruju iskazalo je $13 \%$, a bez odgovora je bilo $9,9 \%$ ispitanika.

Da li vjerujete u postojanje uskrsnuća mrtvih ispitanici su odgovorili na sljedeći način: $50 \%$ ispitanika vjeruje; nisu sigurni njih $23 \%$, ne vjeruju njih $18,7 \%$, a bez odgovora je $7,5 \%$.

Na pitanje da li vjeruju u postojanje grijeha, vjeruje čak 76,6 \% ispitanika. Nije sigurno $13,1 \%$, zatim 3,6 \% ne vjeruje u postojanje grijeha a bez odgovora je $6,6 \%$ ispitanika.

Krštenje spada među 3 obredne aktivnosti koje ne spadaju u 7 kršćanskih sakramenata/svetih tajni. Na ovo pitanje njih 41,7 \% odgovara da ne spada. Nadalje, 16,7 \% ispitanika izjašnjava se da ne zna. Bez odgovora je ostalo $41,7 \%$ ispitanika.

Da je krizma/miropomazanje među 3 obredne aktivnosti koje ne spadaju u 7 kršćanskih sakramenata, potvrdilo je da ne spada 78,6 \% ispitanika. Da ne znaju izjasnilo se 9,5\% ispitanika, a bez odgovora je bilo 11,9\%.

Pričest ili euharistija spada među 3 obredne aktivnosti, a koje ne spadaju u 7 kršćanskih sakramenata, izjavilo je da ne spada 53,3\% ispitanika. Nadalje, ne zna njih 13,3\%, a bez odgovora je bilo $33,3 \%$.

Ispovijed ili pokora spada među 3 obredne aktivnosti, a koje ne spadaju u 7 kršćanskih sakramenata je potvrđeno od strane da ne spada 46,2 \% ispitanika. Da ne znaju izjasnili su se 23,1 \%, a bez odgovora je bilo 30,8 \%.

Obrezivanje spada među 3 obredne aktivnosti, a koje ne spadaju u 7 kršćanskih sakramenata potvrdilo je da ne spada $93.3 \%$ ispitanika. Bez odgovora je bilo 3,4 \% ispitanika, koliko i njih koji su se izjasnili da ne znaju.

Misa/liturgija spada među 3 obredne aktivnosti, a koje ne spadaju u 7 kršćanskih sakramenata potvrdilo je da ne spada $77,4 \%$ ispitanika. Ne zna $6,5 \%$ ispitanika, te nema odgovora njih $16,1 \%$.

Svećenstvo/red spada među 3 obredne aktivnosti, a koje ne spadaju u 7 kršćanskih sakramenata je potvrđeno da ne spada u velikom postotku i to 86,4\%. Po $6,8 \%$ ispitanika ne zna ili nije dalo odgovor na ovu tvrdnju. 
Bolesničko pomazanje/jelosvećenje spada među 3 obredne aktivnosti, a koje ne spadaju u 7 kršćanskih sakramenata potvrdilo je da ne spada 83,3 \% ispitanika. Da ne zna odgovorilo je 7,4 \%, a nije dalo odgovor njih 9,3\%.

Pomazanje spada među 3 obredne aktivnosti a koje ne spadaju u 7 kršćanskih sakramenata - potvrdilo je da ne spada čak $83 \%$; ne zna $11,1 \%$ a bez odgovora je bilo $8,5 \%$.

Brak spada među 3 obredne aktivnosti, a koje ne spadaju u 7 kršćanskih sakramenata - da ne spada odgovorilo je 66,7 \% ispitanika. Zatim 11,1\% ispitanika ne zna, a bez odgovora na ovo pitanje je bilo $22,2 \%$.

Slijedi pitanje da li je jevrejima dozvoljeno da pale svjetlo na Sabat? Odgovori su sljedeći: 16,5\% ispitanika smatra da je dozvoljeno; da nije dozvoljeno smatra $8,2 \%$ ispitanika; bez odgovora je bilo najviše ispitanika i to $75,3 \%$.

Da je jevrejima dozvoljeno da spremaju hranu za vrijeme Sabata - potvrdilo je samo $22,2 \%$ ispitanika. Da nije dozvoljeno, izjasnilo se $14,8 \%$ ispitanika, a bez odgovora je bilo $63 \%$ ispitanika.

Da li je jevrejima dozvoljeno voziti auto za vrijeme Sabata - potvrdno je odgovorilo 10,8 \%, a da nije dozvoljeno smatra $14 \%$. Najveći broj ispitanika nije dao odgovor i to $75 \%$.

Slično je situacija sa pitanjem dozvole korištenja telefona. $72 \%$ ispitanika je bilo bez odgovora. Da nije dozvoljena upotreba telefona jevrejima na Sabat smatra $11,7 \%$, a da jeste odgovara $16 \%$ ispitanika.

Na pitanje koje od navedenih pojmova označava jedno od 5 dnevnih molitvi muslimana, ispitanici daju sljedeće odgovore: selam 5,3\%, džuma $13 \%$, namaz 28,2 \% ispitanika, jacija 4,6 \%. Bez odgovora je bilo 38,9 \% ispitanika.

Vezano za religijske vođe u islamskoj zajednici, na pitanje koji je muftija po redu, odgovori su bili sljedeći: najviše ispitanika tačnije $26,8 \%$ smatra da je muftija drugi po redu; da je prvi odgovorilo je 4,9 \% ispitanika, a treći 7,7 \%.

Vezano za religijske vođe u islamskoj zajednici, na pitanje koji je imam po redu, odgovori su bili sljedeći: da je imam treći u hijerarhiji odgovorilo je 21,8 \% ispitanika. Nadalje, 8,5\% ispitanika odgovorilo je da je imam na prvom mjestu, a 9,2\% ispitanika odgovorilo je da je imam na drugom mjestu.

Vezano za religijske vođe u islamskoj zajednici, na pitanje koji je reisu-1ulema, odgovori su bili sljedeći: da je prvi odgovorilo je $27,5 \%$ ispitanika, a da je drugi i treći, ukupno je odgovorilo $12 \%$ ispitanika.

Na pitanje da li znaju po hijerarhiji poredati religijske vođe muslimana, njih $66,7 \%$ ispitanika je odgovorilo potvrdno. 
Muslimani imaju svoj kalendar i on se računa od koje godine? Najviše ispitanika, tačnije 17,6 \% je odgovorilo da se vrijeme u muslimanskom kalendaru računa od 622 godine. Na ukupno drugih ponuđenih 13 odgovora, ispitanici su sa $7 \%$ odgovorili za 9 ponuđenih odgovora. Četiri odgovora su procentualno dati od $1,4 \%$ i $2,1 \%$.

Koje se godine hrišćanstvo podijelilo na zapadno (katoličanstvo) i istočno (pravoslavno). Na tri ponuđena odgovora, $81 \%$ ispitanika je dalo odgovor da je to bilo 1054. godine. Odgovor nije znalo $8,8 \%$ ispitanika, a 9,5\% ispitanika je odgovorilo da je to bilo 3136 . godine, dok je 1620 . godinu potvrdilo $7 \%$ ispitanika.

Paroh je religijski vođa koji pripada kojoj religijskoj zajednici? Samo je 8,5 \% ispitanika ustvrdilo da paroh pripada katoličkoj religijskoj zajednici.

Župnik je religijski vođa koji pripada kojoj religijskoj zajednici? Većina ispitanika, 96,5 \% je odgovorilo da župnik pripada katoličkoj vjerskoj zajednici. Da pripada pravoslavnoj odgovorilo je 2,4 \% ispitanika a jevrejskoj 1,2 \%.

Vladika/episkop je religijski vođa koji pripada kojoj religijskoj zajednici? U odgovorima je potvrđeno da $97,7 \%$ ispitanika smatra da vladika pripada pravoslavnoj religijskoj zajednici. Da pripada katoličkoj iskazalo je 2,3\% ispitanika.

Biskup je religijski vođa koji pripada kojoj religijskoj zajednici? Ispitanici su sa 93,8 \% odgovorili da je biskup vođa koji pripada katoličkoj religijskoj zajednici. Da pripada pravoslavnoj, izjasnilo se $6,3 \%$ ispitanika.

Muftija je religijski vođa koji pripada kojoj religijskoj zajednici? Ispitanici su sa $100 \%$ odgovorili da muftija pripada islamskoj vjerskoj zajednici.

Mitropolit je religijski vođa koji pripada kojoj religijskoj zajednici? Ispitanici sa 96,4 \% odgovora potvrdili su da je mitropolit vođa pravoslavne religijske zajednice. Da je vođa katoličke, odgovorilo je $2.5 \%$ ispitanika.

Papa je religijski vođa koji pripada kojoj religijskoj zajednici? Sa $96 \%$ pravoslavci odgovaraju da papa pripada katoličkoj vjerskoj zajednici. Da pripada pravoslavnoj, odgovorilo je 2,4 \% a jevrejskoj njih $1,2 \%$.

Patrijarh je religijski vođa koji pripada kojoj religijskoj zajednici? U odgovorima je 97,7 \% ispitanika potvrdilo da je patrijarh vođa u pravoslavnoj religijskoj zajednici. Da pripada katoličkoj, iskazalo je 2,3 \% ispitanika.

Rabin je religijski vođa koji pripada kojoj religijskoj zajednici? Ispitanici su odgovorili sa 85,9\% da rabin pripada jevrejskoj religijskoj zajednici.

Reisu-l-ulema je religijski vođa koji pripada kojoj religijskoj zajednici? Ispitanici su, tačnije njih 98,7 \% odgovorili da je u pitanju islamska vjerska zajednica. Da pripada jevrejskoj odgovorilo je 1,3\%. 
U pogledu uloge i kojoj religijskoj zajednici pripadaju, paroh, župnik, vladika, biskup, muftija, mitropolit, papa, patrijarh, rabin, reisu-l-ulema, ispitanici su pokazali visok nivo znanja od $89 \%$ za rabina i čak $100 \%$ za muftiju. I za preostale religijske vođe imamo visok nivo poznavanja: od $91 \%$ do $97 \%$ ispitanika.

Na pitanje znate li ko slavi krsnu slavu, ispitanici su potvrdno odgovorili sa 98,6 \%, da krsnu slavu slave pravoslavci. Samo 1,3\% ispitanika odgovorilo je da krsnu slavu slave jevreji.

Znate li koja je najrasprostranjenija hrišćanska molitva? Da je to Oče naš odgovorilo je 87,9 \% ispitanika. Dok je za molitvi Zdravo Marija odgovorilo $7,1 \%$. Samo $5 \%$ ispitanika nije znalo odgovor.

Kada je u pitanju najznačajniji hrišćanski blagdan, od 11 ponuđenih odgovora, ispitanici su sa 47,2 \% odgovorili da je to Božić, a $35 \%$ ispitanika smatra da je to Vaskrs.

Na pitanje koji je simbol hrišćanstva, ispitanicu su odgovorili, tačnije njih $85,2 \%$ da je to krst. Na ostale ponuđene odgovore, četiri, njih $7 \%$ je dalo različite odgovore.

Rođenje poslanika Muhameda je jedan od najpoznatijih praznika kod muslimana. Njih $100 \%$ je odgovorilo da je rođenje poslanika Muhameda jedan od najpoznatijih praznika kod muslimana.

Da su Ramazanski i Kurban-bajram najpoznatiji praznici kod muslimana ispitanici su potvrdili sa $100 \%$.

Na ponuđene odgovore da katolici u nedjelju idu na službu, svetu misu, bogosluženje, liturgiju, crkvu, ispitanici su sa $65.5 \%$ odgovorili da katolici u nedjelju idu na misu. Drugi odgovori su iskazani sa $7 \%$.

Da muslimani petkom idu na džumu odgovorilo je $32,4 \%$ ispitanika. Da idu na namaz odgovorilo je 11,3\% ispitanika.

Kod katolika je zadržan obred obrezivanja? Da je zadržan potvrdilo je od ukupnih odgovora 100 \% ispitanika. Za židove također 100 \%. Čak i na pitanje za obred obrezivanja kod pravoslavaca, također su svi odgovorili potvrdno. Za muslimane, obred je zadržan u vrijednosti od 99,2 \% a da nije, odgovorilo je $8 \%$ ispitanika.

Da se židovski vjerski hram naziva sinagoga, odgovorilo je $61,3 \%$ ispitanika. Njih $7 \%$ je odgovorilo da ne zna. Na pitanje šta je simbol jevrejske vjere samo je 40,1 \% ispitanika odgovorilo da je simbol Davidova zvijezda. Ostali ponuđeni odgovori su se kretali u vrijednosti od $7 \%$.

Na pitanje koja je najpoznatija redovnička katolička zajednica u Bosni i Hercegovini, ispitanici su na osnovu više ponuđenih odgovora sa $7 \%$ potvrdili 
da su to: franjevačka, Sestre milosrdnice, i franjevci-benediktanci. Odgovor nije znalo $9 \%$ ispitanika.

Među 5 osnovnih načela koje mora poštovati i živjeti svaki musliman jeste šehadet (ispovijedanje vjere). Ovo je potvrdilo čak 98,6 \% ispitanika pravoslavne vjere.

Ostalanačelaispitanicu supotvrdiliusljedećim vrijednostima:namaz $98,9 \%$, post $98,7 \%$, slavljenje dana nevruza $92,3 \%$, zekat $98,4 \%$, hadž $98,4 \%$.

Na pitanje koji je simbol islama, $14,8 \%$ ispitanika je odgovorilo da je to polumjesec. Da je mjesec i zvijezda odgovorilo je 20,4 \% ispitanika, a da je polumjesec i zvijezda odgovorilo je 11,3\%.

$\mathrm{U}$ odgovorima ispitanika pravoslavaca ispoljen je veoma visok postotak preko $90 \%$ o poznavanju osnovnih načela prema kojima treba živjeti svaki musliman.

Čime upravlja gvardijan? Od ponuđenih odgovora da upravlja župom, samostanom, provincijom, samo je $15 \%$ ispitanika odgovorilo da gvardijan upravlja samostanom. Da upravlja župom odgovorilo je 5,8 \% ispitanika, a provincijom 8,3\%. Odgovor nije znalo 70,8 \% ispitanika. Pokazalo se da dvije trećine ispitanika nikako ne poznaje upravljačku ulogu gvardijana.

Čime upravlja iguman? Ispitanici su pokazali svojim odgovorima sa 71,8 \% da iguman upravlja manastirom a ne parohijom ili episkopijom.

Kako se naziva obavezni milodar, potpisana milostinja kod muslimana? Da je to zekat odgovorilo je $22,5 \%$ ispitanika, a da je to sadaka - odgovorilo je $8,5 \%$ ispitanika.

Da je Šalom pozdrav jevreja potvrdilo je $100 \%$ ispitanika. Selam kao pozdrav muslimana je potvrdilo također $100 \%$ od ispitanih. Hvaljen Isus i Marija je pozdrav katolika - potvrdilo je 99,2 \%. Pomoz Bog je pozdrav pravoslavaca potvrđeno je sa $100 \%$ od ukupne vrijednosti.

$\mathrm{Na}$ ovaj način ispitanici pravoslavci su potvrdili da u potpunosti poznaju pozdrave unutar religijskih zajednica muslimana, katolika, jevreja i pravoslavaca.

Pored islamske, pravoslavne, katoličke i jevrejske zajednice u $\mathrm{BiH}$ postoje i druge: da postoje protestanti, potvrđeno je od strane pravoslavaca $8,5 \%$ ispitanika, adventisti i jehovini svjedoci su potvrđeni sa $7 \%$ ispitanika, romska vjerska zajednica isto sa $7 \%$. Da ne znaju odgovorilo je $7 \%$ ispitanika.

Jeste li posjetili vjerski hram neke druge religijske zajednice osim vaše? $18,5 \%$ ispitanika je potvrdilo da su posjetili druge hramove kao gosti. Njih $27,7 \%$ su kao turisti posjetili druge hramove, a da nije bilo prilike izjasnilo se $26,9 \%$ ispitanika. $10,9 \%$ ispitanika nema radoznalost za to, a $13,4 \%$ je iskazalo da ne žele posjetiti hramove drugih religija. 
Kada su u pitanju drugi razlozi, $7 \%$ ispitanika ne zna, te ista vrijednost je vezana za odgovor da nisu, ali da imaju namjeru.

Na pitanje da li im je poznato da je pripadnik neke druge religije posjetio hram religije kojoj pripadaju, 17,9\% ispitanika je odgovorilo da im nije poznato. Bez odgovora je bilo 13,4 \%, a da je bilo drugih pripadnika kao gost izjavilo je 20,1\%. Najveći broj ispitanika, tačnije njih 48,5\% je odgovorilo da im je poznato da su pripadnici drugih religija kao turisti posjećivali objekt njihove religijske pripadnosti.

U kojoj mjeri se slažete da je hrišćanstvo jedina istinita vjera? Bez odgovora je bilo 17,7 \% ispitanika, niti se slažu niti ne slažu je bilo 21,5 \%, da se djelimično slažu bilo je $18 \%$ ispitanika. Najveći postotak se odnosi na potvrdan odgovor, da je hrišćanstvo jedina istinita vjera i to $30,8 \%$. Kumulativno posmatrano, 49 \% ispitanika se slažu i djelimično slažu da je hrišćanstvo jedina i prava vjera.

Da li je neko iz vaše uže obitelji (dijete, sestra, brat) u braku sa pripadnikom druge nacije? Da jeste odnosno potvrdni odgovor je iskazalo 20,8 \% ispitanika. Da nije odgovorilo je 70,8 \%. Da ne zna odgovorilo je 8,5 \%. Prema ovim odgovorima, samo je jedna petina odnosno $20,8 \%$ ispitanika potvrdilo da su neki članovi njihove uže porodice u braku sa pripadnicima druge nacije. Od onih koji su iz uže porodice ispitanika u braku sa pripadnicima drugih nacija, ispitanici su odgovorili da su to muslimani $25,6 \%$, katolici $7 \%$, židovi $9 \%$ i ateisti 55,8 \%.

Kako se vrednuju ekstremni nacionalisti? Njih 65,2\% ispitanika tvrdi da su muslimani ekstremni nacionalisti. Za katolike je odgovorilo $16 \%$ ispitanika. Pravoslavci su u odgovorima ispitanika ekstremni nacionalisti sa $12,1 \%$ dok su jevreji ekstremni nacionalisti za 1,5\% ispitanika. Ateisti su sa 4,5 \% odgovora okarakterisani kao ekstremni nacionalisti. Za zaključiti je da je percepcija o muslimanima kao ekstremnim nacionalistima došla usljed medijskog tretmana ekstremnih nacionalista u islamskim zemljama.

Vrijednosni sudovi ispitanika o karakternim osobinama muslimana, katolika, židova i ateista iskazuju se u sljedećim procentualnim vrijednostima: impulzivni su: muslimani $36,1 \%$, pravoslavci $34,4 \%$, katolici $16,4 \%$, židovi $6,6 \%$ te ateisti sa $6,6 \%$.

Vrijedni su: muslimani $23 \%$, pravoslavci 49,4\%, katolici 6,9\%, židovi $17,2 \%$, i ateisti sa $3,4 \%$.

Inteligentni su: muslimani $10,4 \%$, pravoslavci $59,7 \%$, katolici $10,4 \%$, židovi $15,6 \%$, i ateisti 3,9\%. 
Vidljivo je da su pravoslavci u visokom postotku vrednovali svoju religijsku grupu, nešto povoljnije jevreje, a sa najnižim postotkom su vrednovali katolike i muslimane.

Kakva je privrženost obitelji? Iskazani su sljedeći vrijednosni sudovi: muslimani 17,6 \%, pravoslavci 49,4 \%, katolici 16,5 \%, židovi $14 \%$, ateisti $2,4 \%$. Za ispitanike pravoslavce, najmanje privrženi obitelji su ateisti i židovi.

Koliko su pripadnici muslimana, pravoslavaca, katolika, jevreja i ateista materijalisti? Odgovori su dati u sljedećim postocima: muslimani 15,4\%, pravoslavci $12,3 \%$, katolici $36,9 \%$, jevreji $26 \%$ i ateisti $9,2 \%$.

Koliko su pripadnici ovih skupina koristoljubivi? Muslimani 28,3 \%, pravoslavci 18,9\%, katolici $24 \%$, jevreji 18,9\% i ateisti 9,4\%.

Koliko su pripadnici ovih skupina muzikalni? Muslimani 30,6 \%, pravoslavci 38,7\%, katolici 12,9\%, jevreji 12,9\% i ateisti 4,8 \%.

Koliko su pripadnici ovih skupina ratoborni? Pravoslavci su potvrđeni sa 43,5 \%, da su muslimani ratoborni smatra 30,6 \% ispitanika, katolici 12,9\%, jevreji $12,9 \%$, ateisti $4,8 \%$. Vidljivo je da su pravoslavci sebe najviše vidjeli kao ratoborne i to u vrijednosti od 43,5\%.

Snalažljivi su prema pravoslavnim ispitanicima pripadnici sljedećih grupa: muslimani $15,9 \%$, pravoslavci su najsnalažljiviji sa 53,5 \%, katolici $11 \%$, jevreji $11,6 \%$ a ateisti su snalažljivi za 7,2 \% ispitanika.

Koliko su temperamentni? Prema mišljenju ispitanika pravoslavaca, pravoslavci su najtemperamentniji sa 63,5 \%. Nadalje, muslimani sa $12,7 \%$, katolici $12,7 \%$, jevreji $11,6 \%$ a ateisti $7,2 \%$.

Da li su pripadnici drugih religija nepristupačni: $24 \%$ ispitanika smatra da su muslimani nepristupačni, pravoslavci $12 \%$, katolici $8 \%$, $30 \%$ smatra da su jevreji nepristupačni, a ateisti $26 \%$.

U pogledu praznovjernosti, vrijednosti su sljedeće: $62,3 \%$ ispitanika potvrđuje praznovjernost kod ateista, jevreji su praznovjerni od 1,9\%, katolici 9,4 \%, a pravoslavci i muslimani su praznovjerni za $13,2 \%$ ispitanika.

Da su religiozni: muslimani 37,7 \%, pravoslavci 29,9\%, katolici 18,2 \%, jevreji $6,5 \%$, a ateisti 7,8 \%.

Duhovitostpripadnikareligijskihgrupa:pravoslavcisunajduhovitiji67,7\%, katolici 4,8 \%, muslimani $16 \%$, jevreji $4,8 \%$ a ateisti $6,5 \%$.

Prevrtljivi su: muslimani $13,5 \%$, pravoslavci $20,5 \%$, katolici $40,9 \%$, jevreji $11,4 \%$ i ateisti $6 \%$.

Tolerantni su: muslimani $8,8 \%$, pravoslavci su najtolerantniji sa $47,4 \%$, katolici $21,1 \%$, jevreji $12 \%$ a ateisti $10,5 \%$. 
Škrtost se javlja u sljedećim vrijednostima: muslimani $15 \%$, pravoslavci $17,2 \%$, katolici $25,9 \%$, jevreji 32,8 \% i ateisti 8,6\%.

Konzervativni su: muslimani 45,5\%, pravoslavci 16,4 \%, katolici $14,5 \%$, jevreji 16,4 \% i ateisti $7 \%$.

Primitivni su: muslimani sa $49 \%$, pravoslavci 14,3\%, katolici 10,2\%, jevreji $6,1 \%$, ateisti $20,4 \%$. Skoro $70 \%$ od ukupno ispitanih smatra da su primitivni muslimani i ateisti.

Naivni su: muslimani $14,5 \%$, pravoslavci $43,6 \%$, katolici 5,5 \%, jevreji $18,2 \%$, a ateisti $18,2 \%$.

Koliko se poštuju pripadnici ostalih religijskih skupina, odgovori su u sljedećim vrijednostima: katolike poštuje $53 \%$ ispitanika pravoslavaca, nema ništa protiv njih $40 \%$, da ih ne vole odgovorilo je samo $0,67 \%$. Pravoslavci se poštuju u vrijednosti od $90 \%$. Muslimane poštuje njih $46 \%$ ispitanika, da nema ništa protiv njih odgovorilo je $42,6 \%$, a da ih ne vole iskazalo je $9,6 \%$. $1,5 \%$ ispitanika odgovorilo je da mrzi muslimane. Ovdje potvrđujemo zanemariv postotak mržnje prema muslimanima.

Kada je u pitanju poštovanje prema jevrejima poštuje ih njih 47,8 \% ispitanika, 44,8 \% ispitanika nema ništa protiv jevreja, a da ih ne voli odgovorilo je 9,6\%. 1,5\% mrzi jevreje.

Pripadnike drugih religijskih skupina/sekti ispitanici poštuju sa 20,7 \%. Protiv ovih grupa nema ništa $20 \%$ njih, dok ih ne voli čak 52,6 \%. Mržnju je iskazalo 6,7 \% ispitanika. Zadnja dva postotka ukazuje na netoleranciju i animozitet prema drugim sljedbama.

Sa pravoslavcem mogu imati prijateljski odnos odgovorilo je 99,2 \% ispitanika. Da ne mogu, iskazalo je $8 \%$ ispitanika.

Sa pravoslavcem mogu imati susjedske odnose ogovorilo je potvrdno 98,4 \% ispitanika, što je u oba slučaja očekivano. Da ne mogu imati susjedske odnose smatra $1,6 \%$ ispitanika.

Da mogu imati poslovne odnose sa pravoslavcima, odgovorilo je 96,8 \% ispitanika, a nastavnika njihove djece za pravoslavca potvrdno je odgovorilo $96 \%$ ispitanika. Nadalje za kućnog prijatelja pravoslavca, $95 \%$ ispitanika je odgovorilo potvrdno, a zeta ili snahu odgovorilo je $98 \%$ ispitanika.

Sa katolikom mogu imati prijateljske odnose smatra 85,5\% ispitanika, a da ne mogu tvrdi $14,5 \%$. Za susjedske odnose sa katolicima, potvrdilo je tvrdnju 83,5\%, a 16,5\% ispitanika smatra da ne mogu imati susjedske odnose sa katolicima. Potvrdne odgovore da mogu imati šefa katolika dalo je 60,9 \% ispitanika, dok je negativno odgovorilo 39,1\%. Slično je sa odgovorima na poslovne odnose sa katolikom: potvrdno je odgovorilo $74 \%$ ispitanika, a 
negativno njih $25 \%$. 62,4 \% ispitanika može imati katolika za nastavnika svoje djece u vrijednosti, dok se $37 \%$ ispitanika usprotivilo ovoj tvrdnji.

Za prijateljske odnose sa katolikom izjasnilo se 74,5 \% ispitanika, dok je protiv prijateljstva bili njih $25,5 \%$. Imati zeta ili snahu katolika potvrdno je odgovorilo $68,1 \%$.

Imati katolika za prijatelja, susjeda, poslovnog partnera, kućnog prijatelja potvrdno je odgovorilo preko $75 \%$ ispitanika pravoslavaca. Za katolika šefa i nastavnika djece potvrdno je odgovorilo $60 \%$ ispitanika.

$\mathrm{Na}$ ista pitanja vezana za pripadnike muslimanske vjeroispovijesti, odgovori su sljedeći: da mogu biti prijatelji sa muslimanima odgovorilo je 83,9\% ispitanika, 77 \% ispitanika smatra da im musliman može biti komšija, 74,8 \% pravoslavaca nema problema da im musliman bude poslovni partner, kućni prijatelj njih $69,8 \%$, zet ili snaha $64,8 \%$. manje povjerenje su ispitanici iskazali da im musliman bude šef 55,3\% i nastavnik njihove djece 60,2 \%.

Povjerenje ispitanika pravoslavaca prema ateistima znatno je manje od povjerenja koje iskazuju prema katolicima i muslimanima. Da mogu imati susjedske i drugarske odnose ispitanici su potvrdno odgovorili sa $64,8 \%$ odnosno $66,7 \%$. U drugim odrednicama, potvrdne vrijednosti se kreću u vrijednostima od nešto više od $50 \%$.

U kojoj mjeri se slažete sa tvrdnjom da kršćani i muslimani vjeruju u istog Boga? Prema odgovorima ispitanika, potpuno se slaže njih 26,3 \%, djelimično 26,3\%. Zbirno posmatrajući, preko polovine ispitanika smatra da kršćani i muslimani vjeruju u istog Boga.

Vezano za pripadnike drugih grupa/sljedbi/sekti, ispitanici smatraju da im treba omogućiti djelovanje u vrijednosti od $46 \%$. Ograničenje njihovih prava zagovara $11 \%$, a samo $8 \%$ ispitanika smatra da im treba osigurati istu slobodu kao i za ostale. Odgovor na ovo pitanje nije dalo 34,3\% ispitanika.

Koliko se osjećate pripadnikom svoje religije? Pripadnicima svoje religije se u potpunosti osjeća $66,2 \%$ ispitanika, djelimično imaju ovaj osjećaj njih $24,3 \%$ ispitanika, nije sigurno 3,7 \%, a bez odgovora je bilo 5,9\% ispitanika.

U kojoj se mjeri osjećate bliskim sa pripadnicima drugih religijskih zajednica? $29 \%$ ispitanika se u potpunosti osjeća blisko, 48,6\% se djelimično osjeća bliskim, nije sigurno $13 \%$ ispitanika, dok njih 6,5\% nije željelo odgovoriti na ovo pitanje.

Na pitanje koliko im je važna pripadnost svojoj religijskoj zajednici, njih 62,3 \% smatra da im je veoma važno. Da im je djelimično važno smatra 22,5 \%, a da im nije ni važno niti nije važno smatra $10 \%$ ispitanika. Čak $80 \%$ ispi- 
tanika je u kumulativnim vrijednostima potvrdilo da im je važna pripadnost svojoj religijskoj zajednici.

Kako biste opisali svoj odnos prema nacionalnoj pripadnosti? Ispitanici odgovaraju na sljedeći način: njih 37,3 \% iskazali su da prihvataju svoju nacionalnost, ali da mnogo ne razmišljaju o tome. Da je nacionalna pripadnost važan dio njihovog života smatra $6,7 \%$ ispitanika, dok za $8,2 \%$ ispitanika nacionalna pripadnost nije važna. Odgovor nije dalo 4,3 \% ispitanika pravoslavne vjeroispovijesti.

Kojim jezikom govorite, kako nazivate svoj maternji jezik? Da je to srpski jezik odgovoriloje 93,5\% ispitanika. Bez odgovora na ovo pitanje je bilo 3,6 \%. Bosanskim ili nekim drugim jezikom govore prema ovom izjašnjavanju njih $1,4 \%, 7 \%$ ispitanika koriste drugi naziv za svoj maternji jezik.

Kada neko ko nije pripadnik vaše religije kritikuje pripadnike vaše religije, da li se osjećate lično kritikovan? Kao ličnu kritiku doživljava njih 28,8 \%, dok su se za odgovor djelimično odlučilo 40,3 \% ispitanika. Da uopšte to ne doživljavaju kao ličnu kritiku smatra $20 \%$ ispitanika, dok njih $10 \%$ nije dalo odgovor na ovo pitanje. Vidljivo je da $68 \%$ ispitanika kritiku pripadnika svoje religijske zajednice doživljavaju i kao ličnu kritiku.

Na tvrdnju da kršćani i muslimani mogu živjeti zajedno imajući svako svoju vjeru, 47,8 \% ispitanika je dalo potvrdan odgovor. Sa ovom tvrdnjom se djelimično slaže 23,9\% ispitanika, a da se niti slažu niti ne slažu smatra 12,3\%. Djelimično se slažu ili se potpuno ne slažu sa ovom tvrdnjom iskazalo je 6,6 \%. Od ukupnog broja, njih 10,8 \% nema odgovor ili ga ne znaju.

Odgovori na ovu konkretno postavljeno tvrdnju pokazuju da većina pravoslavaca ispitanika smatra da hrišćani i muslimani mogu živjeti zajedno. Naspram teze partijsko-političkih zagovornika da zajednički život nije moguć: zajednički život Srba sa Bošnjacima i Hrvatima.

Živim u bračnoj zajednici sa osobom druge religijske pripadnosti i dobro se slažemo: od ukupno ispitanih koji su odgovorili na ovo pitanje sa potvrdnim odgovorom imamo $100 \%$. Isto je tako i sa tvrdnjom da u porodici imaju člana neke druge religijske zajednice. Identična vrijednost je sa tvrdnjama za susjeda, kolegu na poslu te da imaju pozitivno iskustvo u svim navedenim slučajevima.

Na tvrdnju da: čestitam, odlazim, pozivam i proslavljam sa prijateljima druge vjeroispovijesti sve praznike ne opterećujući se razlikama: ispitanicu su sa $100 \%$ odgovorili potvrdno. Za odnose u kojima se samo čestita, ne odlazi, ne poziva, ne proslavlja sa drugima odgovorilo je $83,3 \%$ ispitanika. Da se ne čestita, niti odlazi na praznike, kumulativna vrijednost je $100 \%$. 
Maksimalne kumulativne vrijednosti su date i u odgovorima: da se čestita i poziva, ali ne sve zajedno, jer ovisi od vjeroispovijesti zvanica, da se pripadnici drugih vjeroispovijesti pozivaju samo na godišnjice i rođendane, da se čestita samo telegramom, sms-om bez zajedničkog slavlja. Posljednju tvrdnju je potvrdilo $98,2 \%$ ispitanika.

Smatrate li da neki ljudi odlaze u vjerske hramove radi društvenog statusa, da bi bili viđeni? $\mathrm{Na}$ ovo pitanje potvrdan odgovor je dalo $39 \%$ ispitanika. Njih 23,5\% ispitanika smatra da nisu sigurni u ovu tvrdnju. Bez odgovora je bilo $8,8 \%$ ispitanika.

Kakav je vaš stav prema religiji? Najviši procenat, tačnije 37 \% ispitanika da su pravoslavlje, islam i katoličanstvo dobar okvir za vjeru i važan pozitivan faktor i korektor.

Kako gledate na međureligijske odnose danas? Najviše ispitanika, njih $37,3 \%$ smatra da se međureligijski odnosi pogoršavaju te ako ovako nastave, da može doći do novih religijskih sukoba.

Religije su danas u krizi, jer je vjera u krizi zato što čovjek iz temelja mijenja svoj odnos prema Bogu. Na ovu tvrdnju $100 \%$ ispitanika. Sa istom vrijednošću ispitanici su odgovorili da je religija u krizi zbog potrošačkog načina života te da ne uspijeva odgovoriti na vjerske potrebe ljudi. Slijedi i odgovor da je religija u krizi zbog sekularnih ideologija i sekti koje spretno zavode narod. Religija je, prema ispitanicima, u krizi, jer je popustila modi i iskušenjima koje nudi bezbožni svijet. 